\title{
JURNAL VISUALISASI SINDROM SANGKAR KOSONG PADA FILM “MARAK”
}

Oleh:

Pius Rino Pungkiawan, M.Sn.

Alumni ISI Yogyakarta

\begin{abstract}
Intisari
Penurunan kondisi fisik, psikis, dan sosial membawa rasa kurang percaya diri, tidak berguna, kesepian bahkan depresi. Kemudian, rasa kesepian dan depresi karena kurangnya dukungan sosial keluarga khususnya anak dalam istilah psikologi dikenal sebagai sindrom sarang kosong. Sebagian besar perhatian manusia berfokus pada perkembangan dan pembangunan yang hanya identik dengan kaum muda. Banyak orang tua yang lebih fokus pada perkembangan dan permasalahan anaknya daripada orangtuanya atau kakek neneknya yang sudah lansia dan tidak produktif lagi. Fenomena sindrom sarang kosong menjadi perlu diperhatikan karena masalah lansia sering terlupakan. Sindrom sarang kosong tidak bisa dilihat secara fisik sehingga butuh visualisasi untuk dapat mengerti bagaimana sindrom tersebut terjadi. Karya ini mefokuskan pada visualisasi sindrom sarang kosong yang diderita lansia. Visualisasi akan menggunakan metode penggunaan unsur naratif dan sinematik film. Dengan demikian diharapkan penonton dapat ikut merasakan sindrom sangkar kosong yang divisualisasikan dalam karya ini.
\end{abstract}

Kata-kata Kunci : Lansia, sindrom sarang kosong, visualisasi.film 


\begin{abstract}
Decreased physical, psychological, and social conditions bring a sense of lack of confidence, uselessness, loneliness and even depression. Then, the sense of loneliness and depression due to the lack of social support of the family especially the child in psychological terms is known as empty nest syndrome. Much of human attention focuses on development and development that is only identical with youth. Many parents are more focused on the development and problems of their children than their parents or grandparents who are elderly and no longer productive. The phenomenon of empty nest syndrome to be noted because the problems of the elderly are often forgotten. The empty nest syndrome can not be seen physically so it takes visualization to be able to understand how the syndrome occurs. This work focuses on visualizing the empty nest syndrome suffered by the elderly. Visualization will use the method of using narrative and cinematic elements of film. It is expected that the audience can share the empty cage syndrome visualized in this work.
\end{abstract}

Key Words: Elderly, empty nest syndrome, visualization.films

\title{
A. PENDAHULUAN
}

Kusumoputro (BPS, 2006: 2) menyebutkan bahwa proses menua adalah proses alami yang disertai adanya penurunan fisik, psikologis maupun sosial yang saling berinteraksi satu sama lain. Peningkatan populasi kelompok lanjut usia diikuti pula dengan berbagai persoalan bagi lanjut usia itu sendiri. Penurunan kondisi fisik, psikis, dan sosial membawanya pada rasa kurang percaya diri, tidak berguna, kesepian bahkan depresi (Siti Partini,2011:3). Kemudian, rasa kesepian dan depresi karena kurangnya dukungan sosial keluarga tersebut dalam istilah psikologi dikenal sebagai sindrom sarang kosong atau empty nest syndrome.

Fenomena empty nest menjadi perlu diperhatikan karena masalah lansia sering terlupakan. Sebagian besar perhatian manusia berfokus pada perkembangan dan pembangunan yang hanya identik dengan kaum muda. Banyak orang tua yang lebih fokus pada perkembangan dan permasalahan anaknya daripada orangtuanya atau kakek neneknya yang sudah lansia dan tidak produktif lagi. Padahal lansia juga memiliki hak sama kesejahteraan sama seperti kaum muda. Hal ini karena usia lanjut merupakan periode akhir masa kritis untuk mengevaluasi kesuksesan dan kegagalan seorang menghadapi masa kini dan masa depan di tengah perubahan-perubahan yang mengalami penurunan. Oleh karena itu dibutuhkan sebuah karya seni yang mampu menyadarkan pentingnya memahami lebih jauh keadaan psikososial lansia seperti sindrom sarang kosong.

Karya video ini akan mefokuskan pada visualisasi sindrom sarang kosong yang diderita lansia. Visualisasi akan menggunakan metode penggunaan simbol dan angle kamera. Selain itu penggunaan long take akan banyak ditekankan. Dengan demikian diharapkan penonton dapat ikut merasakan sindrom sangkar kosong dalam karya ini. 


\section{B. TINJAUN PUSTAKA}

\section{Sindrom Sarang Kosong atau Empty Nest Syndrome}

Beberapa ahli telah mendefinisikan sindrom sarang kosong yang memperkuat kajian karya ini. Sindrom sarang kosong mengacu pada perasaan tertekan, kesedihan dan atau duka cita yang dialami oleh orang tua setelah anak-anaknya meninggalkan rumah setelah dewasa atau berumah tangga. Hal ini dapat terjadi ketika anak-anaknya pergi karena kuliah atau menikah (Cushman, 2005). Siti Partini(2011: 84) juga mendefisikan the empty nest syndrome sebagai suatu kondisi dimana perempuan menjadi depresi setelah anak terakhirnya menikah dan meninggalkan rumah. Seperti sarang yang kini sudah kosong ditinggalkan anak-anak.

\section{Angle kamera}

Joseph V. Mascelli, A.S.C memberikan banyak penjelasan dan pentingnya angle kamera sebagai bentuk visualisasi dramatik. Pemilihan angle kamera yang seksama akan bisa mempertinggi visualisasi dramatik dari cerita (Mascelli:1986). Angle kamera yang digunakan untuk visualisasi karya ini berdasar pada penempatan sudut arah pandang dari ketinggian atau level kamera sebagai bentuk penekanan. Sudut arah pandang ketinggian kamera secara umum memiliki tiga jenis, yaitu high angle, eye level, dan low angle.

3. Naratif dan Sinematik

Karya ini merupakan karya seni video yang menggunakan bentuk film pendek sebagai cara untuk memvisualisasikan sindrom sarang kosong. Secara umum film dibagi atas dua unsur yaitu naratif dan sinematik (Pratista, 2008:1). Sarang kosong mengakibatkan konflik yang mendalam tentang kenangan-kenangan masa lalu yang saat ini sudah tidak ada lagi. Sindrom tersebut tidak bisa dilihat secara kasat mata sehingga butuh sebuah visualisasi untuk mengkomunikasikannya

\section{METODELOGI}

Metode penciptaan "Marak" mengacu pada beberapa model tahapan penciptaan. Kerangka berpikir metode penciptaan dapat dilihat sebagai berikut: 
Bg. 1. Kerangka berpikir

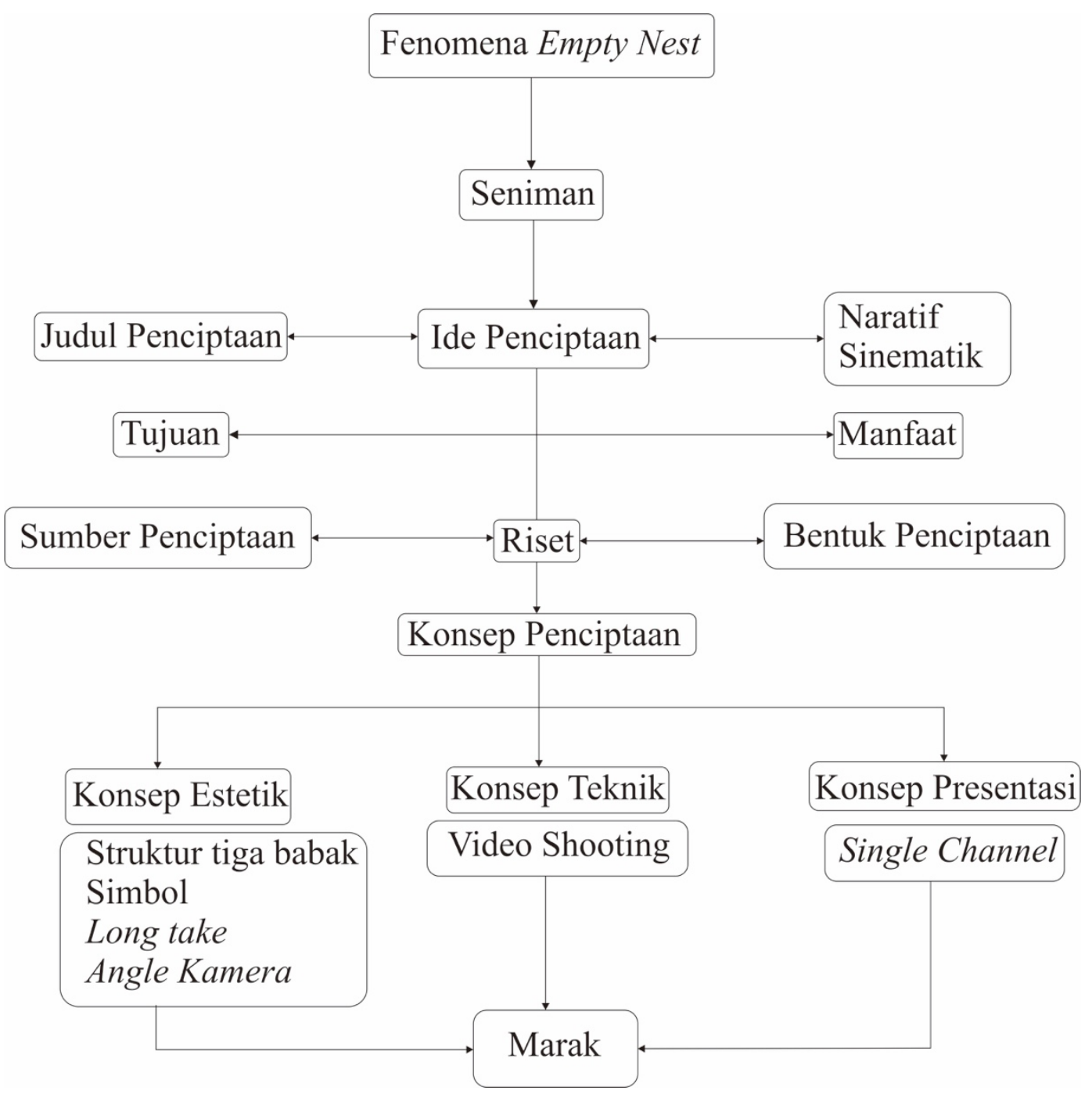

Pada tahap perwujudan, akan diterapkan metode penciptaan seperti yang biasa digunakan dalam produksi film dan televisi dengan terminologi yang lebih sistematik. Cleve (2006: 9) menyebutkan ada empat tahap dalam produksi film yaitu development, preproduction, production, dan post-production. Development adalah tahap pengembangan ide. Pre-production mencakup persiapan-persiapan sebelum produksi dilakukan. Production adalah wilayah pengumpulan materi, shooting dan sebagainya sedangkan postproduction adalah tahap penyusunan materi menjadi bentuk akhir yang siap ditonton. Sedangkan Millerson (2009: 51) menamakan tahapan penciptaan dalam produksi "The Three Stages of Production” yang meliputi planning and preparation, production dan postproduction. Planning and preparation adalah tahapan persiapan atau biasa dikenal juga dengan tahap pra-produksi, Production adalah tahapan produksi itu sendiri. Sedangkan post-production adalah tahapan penyempurnaan seperti editing, ilustrasi musik, mixing sampai dengan duplikasi. Karya ini menggunakan tiga tahapan yang dikemukakan Millerson, yaitu pra-produksi, produksi, dan paska produksi. 


\section{PEMBAHASAN}

Karya video "Marak" dibahas dalam bentuk struktur tiga babak. Pertama, babak eksposisi (pengenalan), kedua bagian konfrontasi yang didalamnya terdapat konflik dan klimaks, dan selanjutnya bagian resolusi hingga ending film. Pembahasan karya dilakukan pada setiap scene untuk memberikan ulasan penuh terhadap karya. Pembahasan dimulai dari unsur naratif, sinematik serta pembahasan. Secara khusus untuk pembahasan tentang simbol akan dibahas melalui pembahasan simbol menurut herusatoto dan secara khusus akan menggunakan tanda menurut peirce. Namun secara umum penonton bebas untuk membaca simbol atau tanda yang ada pada karya ini.

A. Opening

1. Naratif

Ibu duduk terdiam dan sesekali memandang kamar Adi. Nampak Adi sedang memasukkan baju ke dalam tas. Mata ibu berpaling ke ruang tengah dan ketika kembali melihat ke kamar Adi sudah kosong.

2. Sinematik

Pengambilan long shot dengan foreground miniatur kapal layar dan baju pelayaran. Kemudian diikuti dengan shot high angle Ibu. Low key lighting selalu digunakan dalam keseluruhan film.

3. Audio

Suara didominasi oleh suara atmosfer yang ada. Dengan suara angin dan detail suara-suara tas dan almari yang ditimbulkan karena kegiatan yang dilakukan Adi.

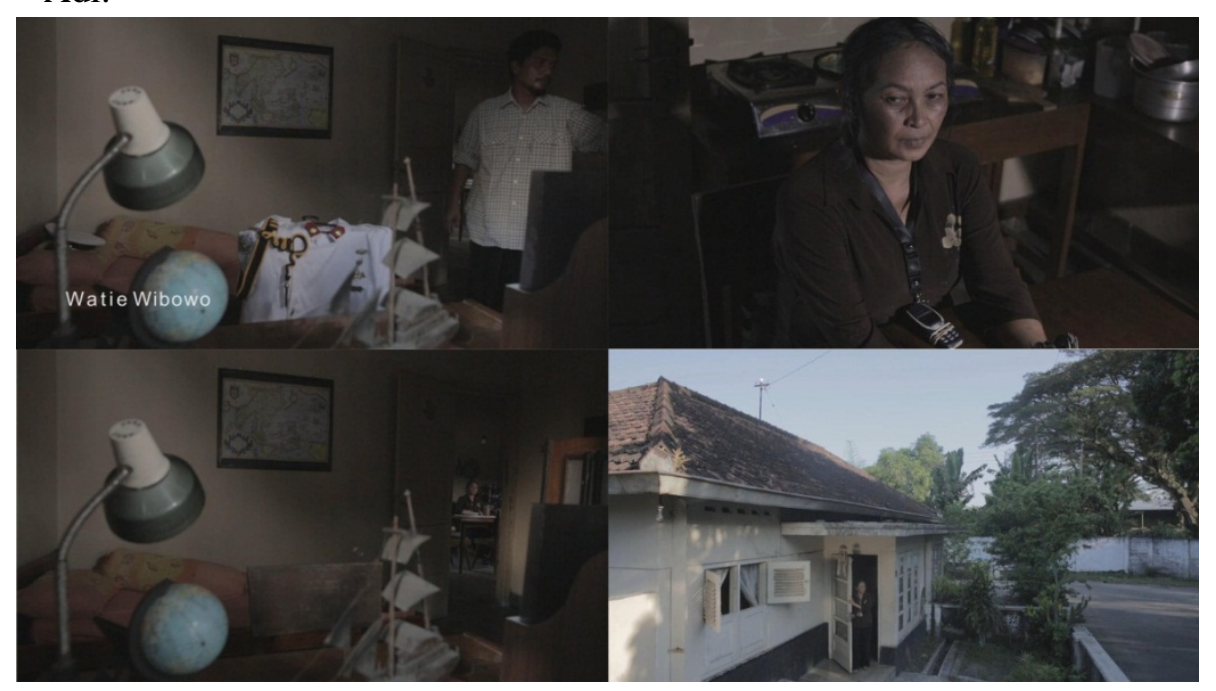

Gb. 17. Screenshot film "Marak” opening

Scene ini merupakan scene imajinasi dimana ibu berhalusinasi tentang anaknya yang masih ada dirumah. Scene diawali dengan memperlihatkan tokoh Adi yang sedang bersiap-siap untuk pergi. Halusinasi ditunjukkan dengan secara tiba-tiba Adi menghilang. Keadaan ibu nampak lemas dan tidak bersemangat melihat Adi yang sedang berkemas. 
Keadaan depresi yang dialami ibu mengakibatkan munculnya imajinasi kepergiaan anaknya dan divisualisasikan dengan high angle. High angle digunakan untuk memberikan efek tertekan dan rasa tidak nyaman. Adegan dalam scene ini merupakan lanjutan dari adegan klimaks dari film marak, dan dibuat sebagai pengenalan awal tentang hal yang dibicarakan tentang kekosongan ibu. Oleh karena itu adegan ini diberikan untuk opening scene film "Marak".

Dari visualisasi diatas dapat dirasakan ketika opening film penonton dibuat merasa bertanya dan mulai tidak nyaman dengan sajian visual yang ada. Berbagai simbol dimunculkan pada mise en scene. Simbol-simbol tersebut digunakan sebagai bentuk penjelasan tentang tiga dimensi tokoh, seperti kapal layar, seragam pelayaran, globe atau bola dunia dan lain sebagainya. Jika menggunakan bahasa tanda peirce, tanda ikonik diperlihatkan dengan miniatur kayu kapal layar untuk memberikan penonton pemahaman tentang profesi yang dijalani oleh Adi. Selain simbol berupa properti juga terdapat simbol berupa gerak dan ekspresi yang dimunculkan. Halusinasi tokoh diperlihatkan ketika tidak ada komunikasi antara ibu dan Adi pada adegan ini dan diperlihatkan adi yang tiba-tiba menghilang.

B. Bagian I Eksposisi

1. Naratif

Scene dibuka dengan kegiatan ibu sehari-hari. Ibu sering sekali menelpon anaknya mulai dari pagi hingga larut malam setelah ibu selesai mengurus pekerjaan rumah. Kekosongan sehari-hari diisi ibu dengan membersihkan rumah khususnya kamar Adi. Setelah setiap kegiatan yang selesai dilakukan, ibu merasa kesepian kembali sehingga memutuskan untuk menelpon Adi untuk mengisi kekosongan dalam dirinya. Selama ibu beraktifitas telpon genggam selalu berada didekatnya. Segelas teh hangat selalu mengisi keseharian ibu di setiap aktifitasnya. Adi sering mengirimkan oleh-oleh dari tempat-tempat yang telah dikunjungi untuk ibunya. Karena Adi sering mengirim oleh-oleh membuat kurir paket cukup akrab dengan ibu Adi.

2. Sinematik

Bentuk visualisasi naratif pada bagian eksposisi ini lebih banyak menggunakan montage dan shot wide angle. Tight shot atau shot dengan komposisi gambar lebih dekat dengan tokoh hanya dimunculkan ketika ibu sedang berbicara di telpon dengan Adi atau ketika Ibu mendapatkan lawan berbicara.

3. Audio

Audio diisi dengan suara atmosfer kegiatan ibu. Suara sapu, kemoceng, dan lain sebagainya. 


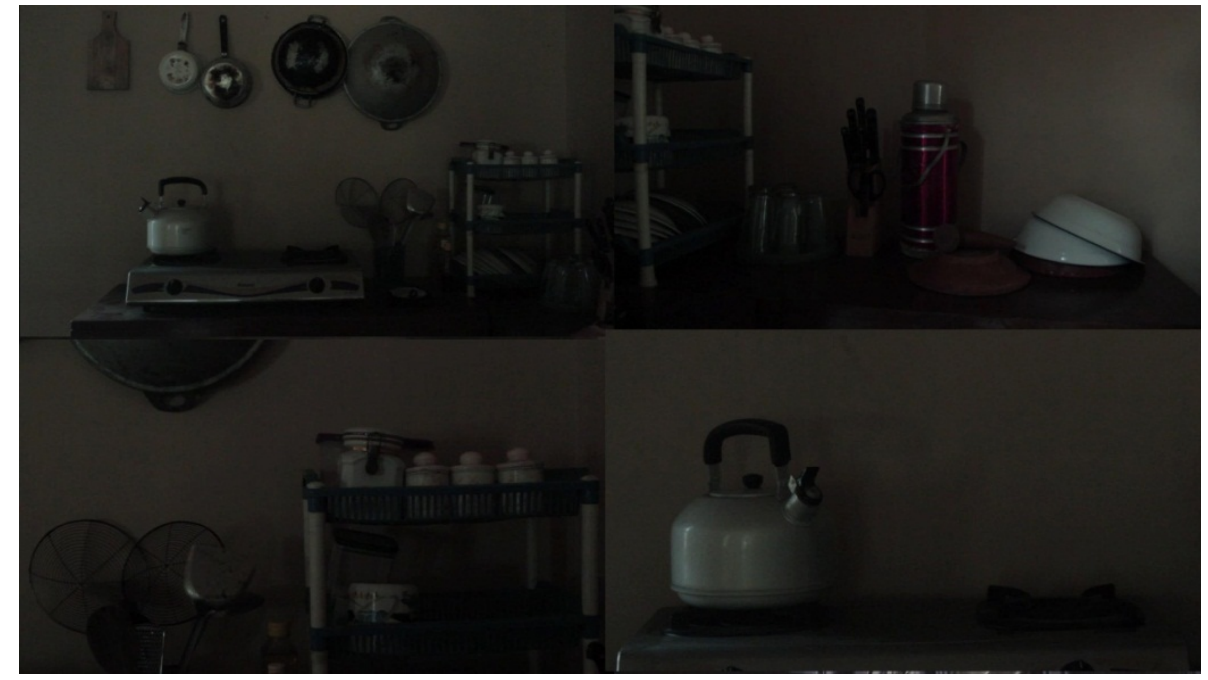

Gb. 1. Screenshot film "Marak" montage dapur

Adegan awal dibuka dengan scene footage isi rumah khususnya dapur. Hal ini dikarenakan kegiatan ibu lebih banyak difokuskan di dapur. Dapur juga menjadi simbol tentang seorang ibu rumah tangga, karena dapur merupakan ruang kerja utama sebagai seorang ibu rumah tangga. Secara visual dapur diperlihatkan sepi dan rapi. Kumpulan shot ini memberikan gambaran kepada penonton tentang karakter Ibu yang rapi dan bersih. Hal ini digunakan untuk juga untuk memberikan perbandingan visual yang jelas ketika kondisi ibu berubah di scene selanjutnya.

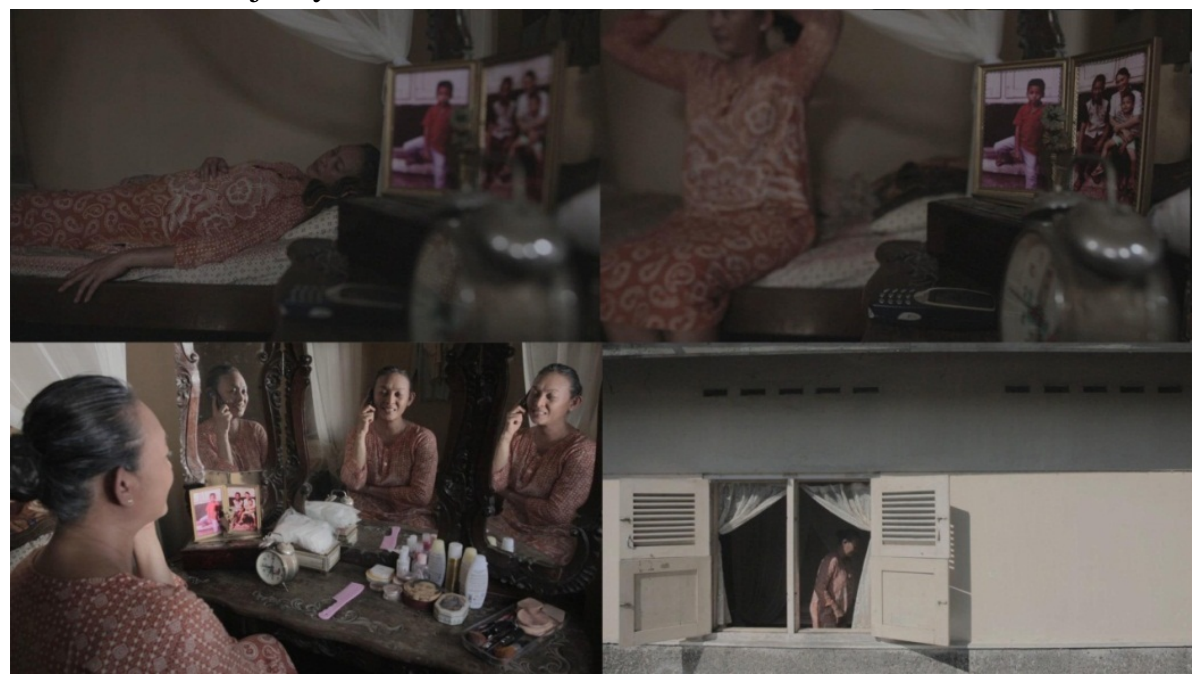

Gb. 2. Screenshot film “Marak” scene kamar ibu

Scene ini merupakan bagian perkenalan pertama tentang kegiatan ibu yang pertama. Penonton diberikan gambaran berbeda dari tokoh ibu pada scene sebelumnya. Dari mise en scene yang ditunjukkan penonton dapat mengidentifikasinya sebagai bentuk flashback dari scene opening sebelumnya. Setiap pagi ibu selalu menelpon Adi setelah bangun tidur sebelum dia memulai aktifitas keseharian lainnya. Pada bagian ini lebih ingin 
mengenalkan sosok ibu dan kondisi kesepian ibu. Perasaan kesepian divisualisasikan dengan pengambilan wide angle. Wide angle menjadi sangat dominan karena dapat memperlihatkan keseluruhan dari setting. Hal tersebut juga memvisualkan kesepian dan kekosongan karena hanya ada sosok seorang ibu yang beraktifitas diantara setting yang luas. Kesepian dan kekosongan juga dibangun dengan atmosfer suara yang dimunculkan dari kegiatan yang dilakukan ibu. Suara lebih banyak dari ruang cerita dan tidak terdapat ilustrasi musik yang melatari. Atmosfer juga dibangun dengan suara burung yang bermunculan.

Ketika Adi menerima telpon dari ibu komposisi gambar mulai berubah, yaitu dari wide angle ke shot tight. Dapat dilihat ketika shot tight ibu duduk di depan cermin, dan memantulkan tiga sosok dirinya. Shot tight dan pantulan sosok ibu di cermin seorang teman yang berdialog, secara visual nampak ibu menjadi tidak sendiri lagi karena terdapat tiga tokoh lain yang ikut muncul di mise en scene. Hal tersebut memberikan pemaknaan tentang terisinya kembali ruang kosong dalam diri ibu melalui telpon yang dilakukan.

C. Bagian II Konfrontasi

1. Naratif

Ibu menerima paket yang dikirimkan Adi. Paket kiriman Adi tidak dibuka dan ditaruh dalam sebuah laci dengan paket kiriman Adi yang lainnya. Ibu langsung menelpon adi dan memberikan kabar tentang paket yang sudah diterima, namun ternyata Adi sedang sakit. Kondisi Adi yang sedang sakit membuat Ibu cemas dan mengharapkan Adi untuk pulang dan tidak melanjutkan perjalanan. Hingga suatu saat ibu mendengar kabar adanya badai dari televisi. Ibu berusasha menelpon adi tapi tidak bisa tersambung. Berkali-kali ibu menelpon Adi tidak tersambung dan tiba-tiba hujan turun, jendela kamar Adi tertiup angin cukup kecang. Ibu berusaha menutup jendela dan seketika itu perasaan yang menjadi lebih khawatir membenarkan berita yang dia terima. Keadaan yang cukup dingin membuat ibu ingin meminum teh hangat. Perasaan khawatir dan depresi membuat kondisi fisik ibu menjadi semakin menurun, sehingga gelas dan telpon genggam ibu terjatuh. Telpon genggam pecah berantakan dan ibu berusaha menyatukan kembali, namun belum selesai memperbaiki telepon genggam tiba-tiba listrik padam.

2. Sinematik

Wide angle, long take dan high angle sangat dominan di bagian konflik. Low key lighting selalu digunakan di keseluruhan adegan.

3. Audio

Audio diisi dengan suara atmosfer ruangan dan sound effect hujan. Scoring musik banyak menggunakan piano dan string. 


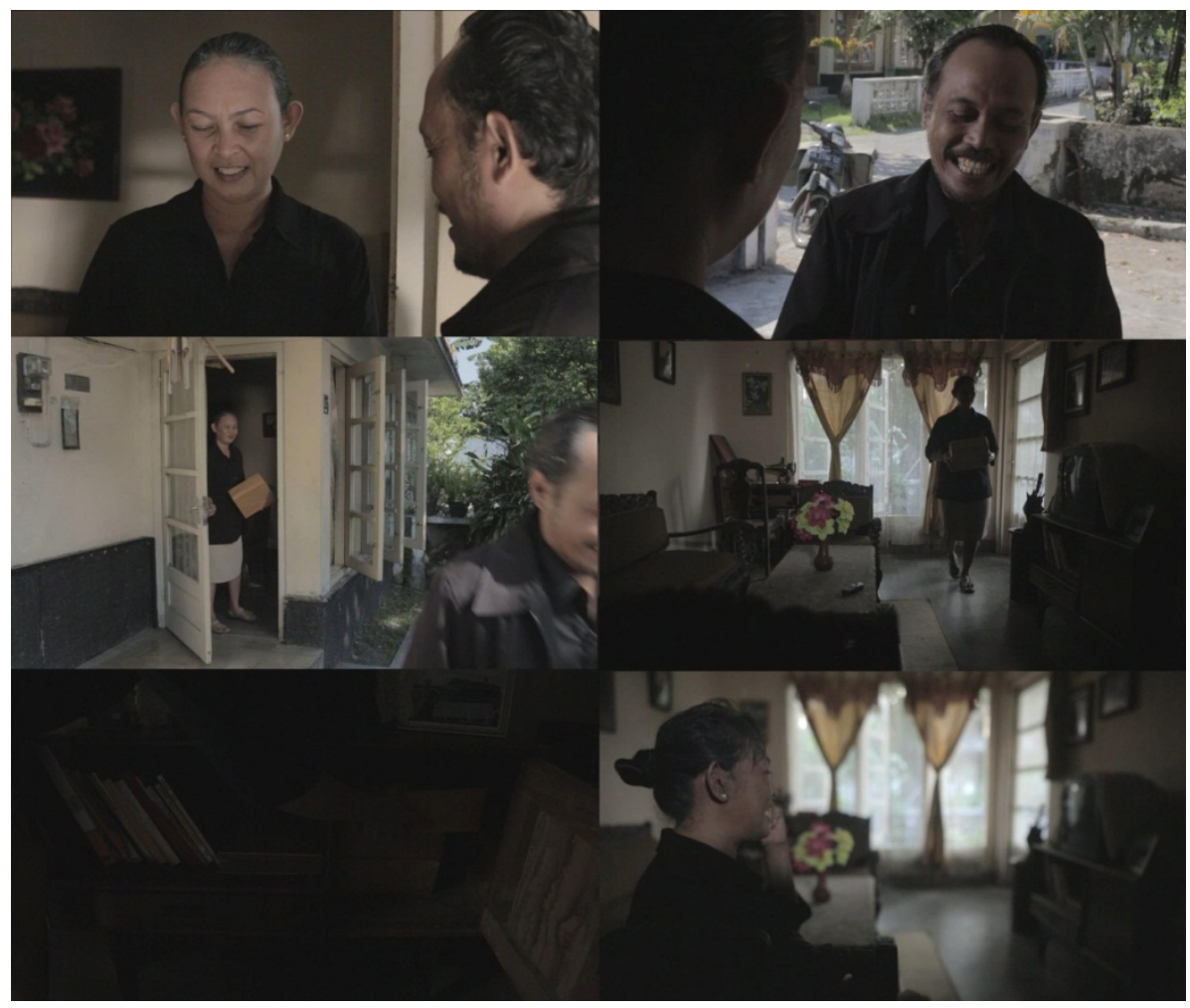

Gb. 3. Screenshot film "Marak" scene kurir paket

Scene ini menunjukkan sebuah rutinitas lain yang dilakukan Adi dan ibunya. Adi selalu mengirimkan paket oleh-oleh yang dikirimkan melalui kurir. Rutinitas Adi ini ditunjukkan dengan dialog antara kurir paket dan ibu. Adegan dimulai dengan kehadiran kurir paket mengetuk pintu dan ibu keluar. Kesan pertama yang dimunculkan adalah kurir paket sudah cukup akrab dengan ibu karena sering sekali datang membawakan paket Adi.

Scene berikutnya adalah ketika ibu menaruh paket di dalam sebuah almari. Di dalam almari nampak sudah ada beberapa tumpukan paket yang sama. Hal tersebut merupakan simbol perasaan ibu yang sebenarnya. Seorang ibu yang mengalami empty nest syndrome atau sindrom sangkar kosong lebih menginginkan kehadiran anaknya daripada sekedar paket atau uang yang dikirimkan. Shot dilanjutkan dengan tight shot ibu menelpon adi. Shot ini dibuat membelakangi kamera dengan posisi wajah sedikit menutup sehingga penonton tidak bisa cukup jelas melihat ekspresi dari ibu. Shot ini dibuat untuk menggambarkan sesuatu yang ditutupi oleh seorang ibu kepada anaknya. Ibu mencoba menutupi perasaan sebenarnya tentang perasaan senang ketika paket tersebut diterima dan paket tersebut tidak pernah dibuka.

Pada bagian konflik ini dimulai dari adegan ketika ibu mendengar kabar tentang Adi yang sakit dan berita tentang gelombang tinggi yang terjadi di lautan. Bentuk visualisasi menggunakan high angle menunjukkan bagaimana perasaan ibu yang depresi terhadap keadaan yang sedang terjadi, didukung dengan long take memberikan kesan lama dan perasaan yang dalam. Penonton diajak untuk benar-benar merasakan perasaan ibu melalui shot ini. 
D. Bagian III Resolusi dan Ending

1. Naratif

Pintu jendela tidak terbuka, pekerjaan rumah terbengkalai, kamar Adi nampak kotor. Nampak ibu sedang duduk di kursi meja makan dengan pandangan kosong dengan mengalungkan telpon genggam. Tiba-tiba ada suara pintu diketuk. Dengan perasaan bingung ibu membukakan pintu. Adi berdiri di depan pintu melihat keanehan yang ada dalam diri ibunya. Ibu yang terlihat senang dan bingung karena ternyata yang datang adalah kurir paket.

2. Sinematik

Wide shot dan tight shot menunjukkan beberapa peralatan dapur yang kotor, diikuti dengan kumpulan shot kamar adi yang kotor.

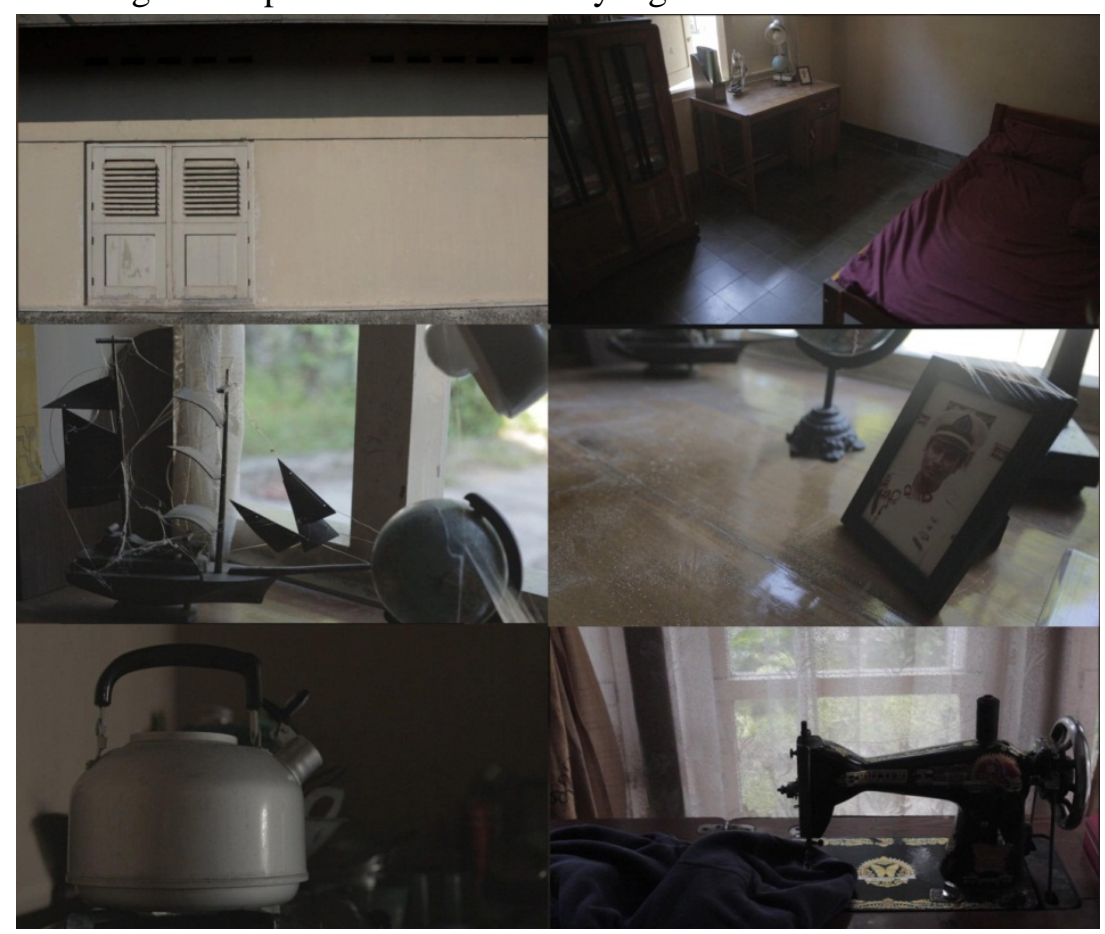

Gb. 4. Screenshot film “Marak” montage scene kotor

Scene dibuka dengan montage pintu jendela yang tidak terbuka, nampak kondisi kamar adi yang kotor dan berdebu, dan ketel yang tidak berbunyi lagi, mesin jahit dengan kain yang masih belum jadi. Tanda-tanda ini merupakan tanda indeks yang menggambarkan kondisi yang berbeda dengan kehidupan keseharian ibu yang selalu bersih dan rapi. Rutinitas ibu sudah tidak dilakukan lagi. Kondisi ini menggambarkan bagaimana keadaan ibu yang tidak memperdulikan lagi lingkungan sekitarnya. Ibu menjadi putus asa dengan hilangnya Adi. Ibu hanya bisa duduk terdiam dan tidak mengerti apa yang harus dilakukannya lagi. 


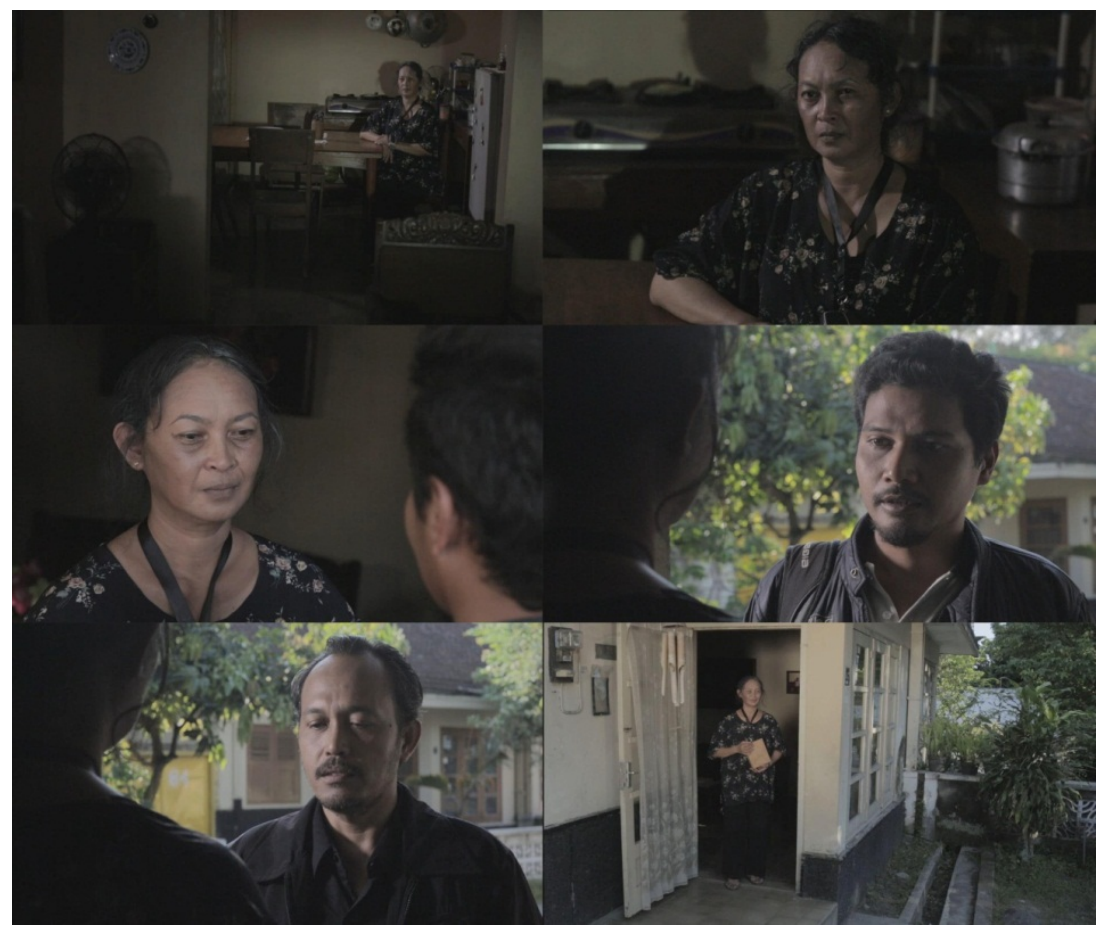

Gb. 5. Screenshot film "Marak” scene ending

Ibu hanya duduk terdiam di meja makan, tiba-tiba terdengar suara pintu diketuk. Ibu keluar membuka pintu dan Adi terdiam di depan pintu melihat ibu yang berubah. Ekpresi ibu nampak kaget dan senang melihat kehadiran Adi, namun tiba-tiba di depan ibu berganti kurir paket yang membawakan paket dari Adi. Scene ini merupakan bentuk visualisasi dari halusinasi ibu. Keinginan bertemu anaknya, harapan untuk bisa bertemu anaknya membuat ibu berhalusinasi melihat sosok adi di depannya. Perasaan yang tidak menentu dirasakan oleh ibu, harapan Adi yang pulang namun hanya sebuah paket yang menjelaskan bahwa Adi masih hidup. Tanda ini juga merupakan tanda indeks karena paket yang didapatkan oleh ibu juga ikut menandakan bahwa Adi masih hidup.

Penonton diajak secara runtut untuk memahami setiap proses dan tahapan sindrom sarang kosong yang terjadi. Hal itu nampak dari mise en scene, mulai dari perubahan setting. Setting diawali dengan keadaan dapur dan yang nampak rapi dan kemudia ditutup dengan keadaan yang terbengkalai. Kemudian dari segi wardrobe tahap demi tahap ditunjukkan dengan perubahan warna yang digunakan dari cerah menuju ke warna-warna gelap. Hal tersebut memperlihatkan emosi ibu yang semakin terpuruk, baju warna hitam yang dipakai ibu merupakan simbol duka cita. Selain itu make up juga memberikan peran cukup besar, perubahan tatanan rambut hingga perubahan fisik diperlihatkan secara bertahap. Diawali dengan kondisi fisik ibu yang sehat, ditunjukkan dengan kegiatan yang dilakukan hingga kondisi fisik ibu yang menurun ditunjukkan dengan raut muka yang kusut dan rambut yang acak-acakan. Segala hal yang dimunculkan merupakan bentuk visualisasi dari sindrom sarang kosong yang dialami, sehingga penonton dapat memahami secara runtut tentang sindrom sarang kosong pada seorang ibu. 


\section{E. KESIMPULAN}

Karya videografi dengan judul "Marak" merupakan bentuk visualisasi sindrom sarang kosong atau empty nest syndrome dengan perpaduan unsur naratif dan sinematik. Unsur sinematik berperan sangat besar dalam memvisualisasikan unsur naratif, dengan penggunaan kamera angle, shot size dan long take dengan perpaduan low key lingting membuat karya ini dapat memberikan look dan mood yang sesuai dengan sindrom yang dirasakan di karya "Marak".

Pendekatan naratif yang digunakan untuk memvisualisasikan sindrom sarang kosong memudahkan penonton menerima pesan dari adegan-adegan yang telah dibuat. Struktur naratif tiga babak menjelaskan secara kronologis mulai dari eksposisi, konfrontasi, relosusi hingga ending. Unsur sinematik yang dibangun sebagai bentuk visualisasi menambah kesan dramatik dan memberikan emosi yang lebih dalam untuk penonton. Sebagai contoh adalah penggunaan shot high angle dan long take pada saat adegan hujan di kamar Adi membawa psikologi penonton untuk merasa sedih dan tertekan.

\section{DAFTAR PUSTAKA}

Badan Pusat Statistik (BPS). (2006), Statistik Penduduk Usia Lanjut 2005, Jakarta, Indonesia: BPS.

Cushman, Robert F.(2005), Psychological Assessment in Medical Rehabilitatio,American Psychological Association. UK.

Pratista, Himawan.2008. Memahami Film. Yogyakarta: Homerian Pustaka.

Mascelli, Joseph V.(1986), The Five C's of Cinematography, Motion Picture Filming Techniques Simplified (Lima Jurus Sinematografi), cetakan kedua, terjemahan H. Misbach Yusa Biran.(2010), Fakultas Film dan Televisi IKJ, Jakarta.

Suardiman, Siti Partini. (2011), Psikologi Lanjut Usia, UGM Press, Yogyakarta. 